Article

\title{
Four New Iridoid Metabolites Have Been Isolated from the Stems of Neonauclea reticulata (Havil.) Merr. with Anti-Inflammatory Activities on LPS-Induced RAW264.7 Cells
}

\author{
Fang-Pin Chang ${ }^{1}$, Shyh-Shyun Huang ${ }^{2}$, Tzong-Huei Lee ${ }^{3}$, Chi-I Chang ${ }^{4}$, Tzong-Fu Kuo ${ }^{5}$, \\ Guan-Jhong Huang ${ }^{6, *}$ and Yueh-Hsiung Kuo 1,6,7,8,*(D) \\ 1 The Ph.D Program for Cancer Biology and Drug Discovery, China Medical University and Academia Sinica, \\ Taichung 404, Taiwan; u101049002@cmu.edu.tw \\ 2 School of Pharmacy, China Medical University, Taichung 404, Taiwan; sshuang@mail.cmu.edu.tw \\ 3 Institute of Fisheries Science, National Taiwan University, Taipei 106, Taiwan; thlee1@ntu.edu.tw \\ 4 Department of Biological Science and Technology, National Pingtung University of Science and Technology, \\ Pingtung 912, Taiwan; changchii@mail.npust.edu.tw \\ 5 Department of Post-Baccalaureate Veterinary Medicine, Asia University, Taichung 413, Taiwan; \\ tzongfu@asia.edu.tw \\ 6 Department of Chinese Pharmaceutical Sciences and Chinese Medicine Resources, China Medical University, \\ Taichung 404, Taiwan \\ 7 Department of Biotechnology, Asia University, Taichung 413, Taiwan \\ 8 Chinese Medicine Research Center, China Medical University, Taichung 404, Taiwan \\ * Correspondence: gjhuang@mail.cmu.edu.tw (G.-J.H.); kuoyh@mail.cmu.edu.tw (Y.-H.K.); \\ Tel.: +886-4-2205-3366 (ext. 5508) (G.-J.H.); +886-4-2205-3366 (ext. 5701) (Y.-H.K.)
}

Received: 18 October 2019; Accepted: 21 November 2019; Published: 23 November 2019

\begin{abstract}
One new iridoid, namely neonanin C (1) one monocyclic iridoid ring-opened derivative namely neonanin D (2), two new bis-iridoid derivatives namely reticunin A (3) and reticunin B (4) with sixteen known compounds (5-20) were isolated from the stems of Neonauclea reticulata (Havil.) Merr. These new structures were determined by the detailed analysis of spectroscopic data and comparison with the data of known analogues. Compounds 1-20 were evaluated for inhibition of nitric oxide (NO) production in lipopolysaccharide (LPS)-stimulated RAW264.7 macrophages cell line. The results showed that all compounds exhibited no obvious cytotoxicity compared to the control group and five compounds including isoboonein (7), syringaresinol (10), (+)-medioresinol (12), protocatechuic acid (14) and trans-caffeic acid (15) exhibited inhibitory activities with $\mathrm{IC}_{50}$ values at $86.27 \pm 3.45 ; 9.18 \pm 1.90 ; 76.18 \pm 2.42 ; 72.91 \pm 4.97$ and $95.16 \pm 1.20 \mu \mathrm{g} / \mathrm{mL}$, respectively.
\end{abstract}

Keywords: Neonauclea reticulata; iridoid; bis-iridoid; neonanin; reticunin; RAW264.7

\section{Introduction}

The genus Neonauclea (Rubiaceae) includes 69 species of diverse trees and shrubs [1]. The plants of this genus are mainly distributed in the Malesian region, extending from India to Vietnam and from Southeast Asia to the northern limits of Australia [2]. Neonauclea reticulata (Havil.) Merr. (N. reticulata) is a large evergreen tree and the only species found in Taiwan, which is located in the forests at low elevations of southern Taiwan, such as Kaohsiung, Pingtung or Orchid [3]. N. reticulata is an important folk plant for Yami people (Tao) who used this plant as a resource to build the keels of bows and sterns in planked boats when they celebrated the flying fish festival on Orchid Island [4]. Phytochemical studies of the genus Neonauclea have been rare and anthraquinones [5], alkaloids [6], triterpenes [7] and 
saponins [8] have been isolated from previous chemical investigations. In our previous study, which is the only study that has mentioned phytochemical investigations about this plant, iridoids, lignans and phenolics were isolated from $N$. reticulata [9]. As for pharmacological activity, two studies have shown N. reticulata can be cytotoxic to Hep cells [9], used to guard against ultraviolet B (UVB) and protect human skin fibroblast cells [10]. Further investigations of the chemical and pharmacological properties of $N$. reticulata are urgently needed.

Inflammation is a complex immune reaction that is triggered by the body during microbial invasion, physical damage or activated by some immune cells such as macrophages. These trigger factors may induce redness, fever, pain and other symptoms in the human body [11]. Sometimes, an appropriate inflammation reaction is beneficial to activate the automatic defense response in the human body for healing and recovery. Unfortunately, excessive defense responses will lead to other human diseases, including Alzheimer's disease, cardiovascular diseases, type 2 diabetes [12], cancers and organ dysfunction [13]. Lipopolysaccharide (LPS) is the main component of the outer membrane of Gram-negative bacteria and is also known as an endotoxin, which rapidly activates macrophages and stimulates the secretion of pro-inflammatory cytokines as well as inflammatory mediators such as nitric oxide (NO) and prostaglandin E2 (PGE2). Because NO plays an important role in the process of inflammation progress, the ability to inhibit production of $\mathrm{NO}$ could be a potential indicator for anti-inflammatory [14].

The aim of this study is to investigate anti-inflammatory ability of $N$. reticulata by using in-vitro NO inhibitory assay in the LPS-stimulated RAW264.7 macrophage cell line and to identify the compounds that mainly contribute to the anti-inflammatory ability and expectantly it can provide the preliminary information for future research in drug discovery of anti-inflammatory agent.

\section{Results and Discussions}

\subsection{Isolation and Structural Elucidation}

In this study, we tested four fractions (MeOH extract, EtOAc fraction, $\mathrm{BuOH}$ fraction and $\mathrm{H}_{2} \mathrm{O}$ fraction that have been described in our previous study) for their cytotoxic activity and inhibition ability of NO produce against the RAW264.7 cells stimulated by LPS. The results showed that four fractions had no significant cytotoxicity. The $\mathrm{MeOH}$ extract and EtOAc fraction exhibited dose-dependent inhibition abilities. (Half maximal inhibitory concentration; $\mathrm{IC}_{50}=465.71 \pm 6.94 \mu \mathrm{g} / \mathrm{mL} \& 350.74 \pm 8.64 \mu \mathrm{g} / \mathrm{mL}$ ). In contrast, $\mathrm{BuOH}$ and $\mathrm{H}_{2} \mathrm{O}$ fractions showed no inhibition of $\mathrm{NO}$. Twenty compounds were isolated from the EtOAc fraction by silica gel column chromatography and normal-phase, semi-preparative, high-performance liquid chromatography (HPLC). Among these compounds, we isolated one new iridoid, which namely neonanin C (1) (neonanin A and B have been reported in our previous study [9]), one monocyclic iridoid ring-opened derivative namely neonanin $\mathrm{D}(2)$, two new bis-iridoid derivatives namely reticunin A (3), reticunin B (4) and sixteen known compounds, including strychnovoline (5) [15], siphonostegiol (6) [16], isoboonein (7) [17], floribundane B (8) [18], alyxialactone (9) [19], syringaresinol (10) [20], (+)-pinoresinol (11), (+)-medioresinol (12) [21], 4-methoxycatechol (13) [22], protocatechuic acid (14) [23], trans-caffeic acid (15) [24], syringic acid (16) [25], 3-hydroxy-1-(4-hydroxy 3,5-dimethoxyphenyl)-1-propanone (17) [26], ferulic acid (18) [27], protocatechuic acid methyl ester (19) [28], C-veratroylglycol (20) [29]. The structures of the new compounds were determined through spectral analyses, including IR, UV, 1D- and two-dimensional (2D)-NMR, as well as HR-ESI-MS data. The known compounds identified were compared with the published NMR spectral literatures. All structures are shown in Figure 1. In this study, we described the detailed structures of the new compounds and the activities of compounds 1-20. 


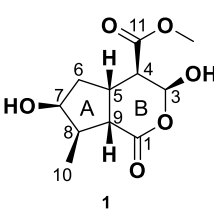

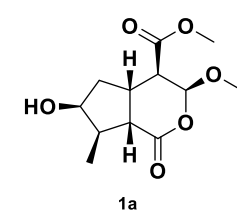

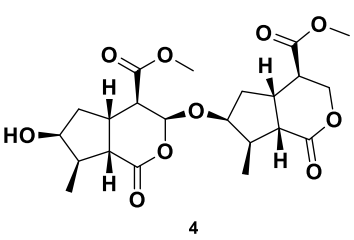

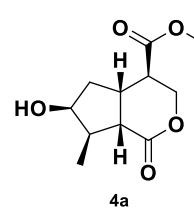

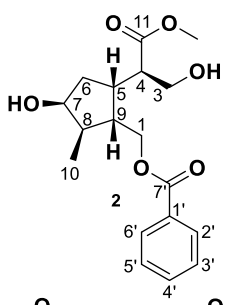

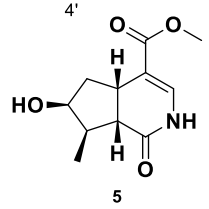

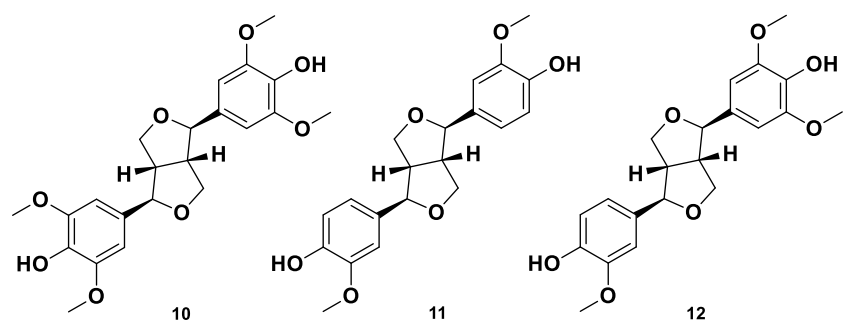<smiles>COc1cc(C(=O)CCO)cc(OC)c1O</smiles><smiles>COc1cc(/C=C/C(=O)O)ccc1O</smiles>

18<smiles>COC(=O)c1ccc(O)c(O)c1</smiles>

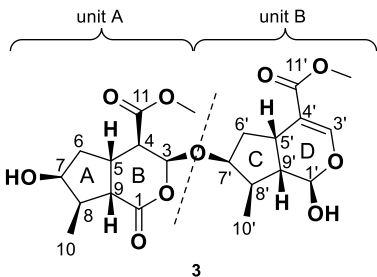<smiles>COC(=O)C1=CC[C@H](O)[C@]2(C)C1CC(O)C(C)C2C</smiles><smiles>COC(=O)C1=CCOC[C@@H]2C1CC(O)C2C</smiles><smiles>CC1C(O)CC2CC(=O)OCC21</smiles><smiles>C/C=C1/C(=O)OCC[C@H]1CCO</smiles><smiles>CC1C(O)CC2NC(=O)OCC2C1O</smiles><smiles>COc1ccc(O)c(O)c1</smiles><smiles>O=C(O)c1ccc(O)c(O)c1</smiles><smiles>O=C(O)/C=C/c1ccc(O)c(O)c1</smiles><smiles>COc1cc(C(=O)C(O)CO)ccc1O</smiles>

20

Figure 1. The chemical structures of compound 1-20 from Neonauclea reticulata (Havil.) Merr.

Compound 1 was obtained as a colorless oil. $[\alpha]_{\mathrm{D}}^{28}+22(c=0.17, \mathrm{MeOH})$. The molecular weight was determined by HR-ESI-MS, which showed an $[\mathrm{M}-\mathrm{H}]^{+}$ion at an $\mathrm{m} / z$ of 243.0870 (calculated for $\mathrm{C}_{11} \mathrm{H}_{15} \mathrm{O}_{6}$ 243.0863), indicating four degrees of unsaturation. The IR spectrum displayed the presence of hydroxyl $\left(3365 \mathrm{~cm}^{-1}\right)$ and $\gamma$-lactone and ester $\left(1730 \mathrm{~cm}^{-1}\right)$ functionalities. The ${ }^{1} \mathrm{H}$ spectra of compound 1 (Table 1) presented a doublet methyl group $\delta_{\mathrm{H}} 1.28(\mathrm{~d}, J=7.0, \mathrm{H}-10)$ and a singlet carbonylmethoxy group at $\delta_{\mathrm{H}} 3.78(\mathrm{~s}, \mathrm{OMe})$; one pair of geminal coupling methylene groups at $\delta_{\mathrm{H}}$ $1.45(\mathrm{td}, J=10.8,3.4, \mathrm{H}-6 \alpha)$ and $\delta_{\mathrm{H}} 2.33(\mathrm{~m}, \mathrm{H}-6 \beta)$; six methine protons including four aliphatic methines at $\delta_{\mathrm{H}} 2.59(\mathrm{dd}, J=10.9,2.1, \mathrm{H}-4), \delta_{\mathrm{H}} 2.88(\mathrm{t}, J=10.9, \mathrm{H}-9), \delta_{\mathrm{H}} 2.30(\mathrm{~m}, \mathrm{H}-8)$ and $\delta_{\mathrm{H}} 3.32(\mathrm{~m}$, $\mathrm{H}-5)$; one oxymethine at $\delta_{\mathrm{H}} 4.14(\mathrm{q}, J=3.4, \mathrm{H}-7)$ and one hemiacetal methine at $\delta_{\mathrm{H}} 5.90(\mathrm{brs}, \mathrm{H}-3)$. The ${ }^{13} \mathrm{C}-\mathrm{NMR}$ spectrum (Table 1) showed 11 signals with the help of distortionless enhancement by polarization transfer (DEPT) and heteronuclear single quantum coherence (HSQC) experiment in the presence of two carbonyl groups $\delta_{\mathrm{C}} 173.7(\mathrm{C}-1)$ and $\delta_{\mathrm{C}} 170.6(\mathrm{C}-11)$. The correlation spectroscopy (COSY) (Figure 2a) correlations with $\mathrm{H}-4\left(\delta_{\mathrm{H}} 2.59\right) / \mathrm{H}-3\left(\delta_{\mathrm{H}} 5.90\right)$ and $\mathrm{H}-5\left(\delta_{\mathrm{H}} 3.32\right) ; \mathrm{H}-5\left(\delta_{\mathrm{H}} 3.32\right) / \mathrm{H}-6$ $\left(\delta_{\mathrm{H}} 1.45\right.$ and $\left.\delta_{\mathrm{H}} 2.33\right)$ and $\mathrm{H}-9\left(\delta_{\mathrm{H}} 2.88\right) ; \mathrm{H}-6\left(\delta_{\mathrm{H}} 1.45\right.$ and $\left.\delta_{\mathrm{H}} 2.33\right) / \mathrm{H}-7\left(\delta_{\mathrm{H}} 4.14\right) ; \mathrm{H}-7\left(\delta_{\mathrm{H}} 4.14\right) / \mathrm{H}-8$ $\left(\delta_{\mathrm{H}} 2.30\right) ; \mathrm{H}-8\left(\delta_{\mathrm{H}} 2.30\right) / \mathrm{H}-9\left(\delta_{\mathrm{H}} 2.88\right)$ and $\mathrm{H}-10\left(\delta_{\mathrm{H}} 1.28\right)$, these findings confirms that a cyclopentanyl moiety with a methyl group and a hydroxyl group in the structure. The key of heteronuclear multiple bond coherence $(\mathrm{HMBC})$ correlations from $\mathrm{H}-4\left(\delta_{\mathrm{H}} 2.59\right) / \mathrm{C}-6\left(\delta_{\mathrm{C}} 42.0\right)$ and $\mathrm{C}-11\left(\delta_{\mathrm{C}} 170.6\right) ; \mathrm{H}-5\left(\delta_{\mathrm{C}}\right.$ $3.32) / C-9\left(\delta_{C} 46.2\right), C-11\left(\delta_{C} 170.6\right)$ and C-1 $\left(\delta_{C} 173.7\right) ; H-9\left(\delta_{C} 2.88\right) / C-1\left(\delta_{C} 173.7\right), C-6\left(\delta_{C} 42.0\right)$ and $\mathrm{C}-10\left(\delta_{\mathrm{C}} 14.1\right)$, From the information of ${ }^{1} \mathrm{H}-\mathrm{NMR}$, DEPT and HSQC spectrums, we determined that C-3 ( $\delta C$ 94.7) is a carbon of hemiacetal methine and the chemical shift was lower than the general range, which proves that the $\mathrm{C}-3$ carbon is connected to the two oxygenated groups. Further, these correlations combined with the IR spectrum indicated that there was a $\gamma$-lactone and ester carbonyl group connected with a pyranyl moiety in the structure. Apart from this, the correlation between 
OMe $\left(\delta_{\mathrm{H}} 3.78\right)$ to $\mathrm{C}-11(\delta \mathrm{c} 170.6)$ supported that a methoxy group was located at C-11. Summarizing the currently available information, we are getting more certain that compound $\mathbf{1}$ is a cyclopenta $[c]$ pyran-type iridoid structure. Thus, the ${ }^{1} \mathrm{H}$ and ${ }^{13} \mathrm{C}-\mathrm{NMR}$ data of 1 were very similar to neonanin $\mathrm{B}$ (compound 1a) [9], except there was only one methoxy group in compound 1. The functional group in the C-3 position of neonanin B was a methoxy group, while a hydroxyl group was located in the C-3 position in compound 1 . The proton of $\mathrm{H}-4$ exhibited two coupling constants, with $J=10.9,2.1$ but the coupling constant of H-3 was not directly shown and was combined with the nuclear overhauser effect spectroscopy (NOESY) correlations (Figure 2b). Even so, we can be sure that the coupling constants and correlations of the NOESY spectrum were also very similar to neonanin B by comparing them to the literature. Thus, the evidence concluded that both of $\mathrm{H}-3$ and $\mathrm{H}-4$ were located in the same phase; the difference is H-3 was located in $\alpha$-pseudoequatorial and H- 4 in $\alpha$-pseudoaxial configuration. The coupling constant with $J=10.9$ between $\mathrm{H}-4$ and $\mathrm{H}-5$ and suggested that $\mathrm{H}-5$ is in a $\beta$-pseudoaxial orientation [30]. This also confirmed H-6 $\beta, H-9$ and methyl group in the $\beta$-configuration, while $H-6 \alpha$, $\mathrm{H}-7$ and $\mathrm{H}-8$ were $\alpha$-oriented. By consolidating the above-mentioned results and comparing them to the literature, to the best of our knowledge, compound $\mathbf{1}$ has been isolated for the first time and assigned to be neonanin $\mathrm{C}$.

Table 1. ${ }^{1} \mathrm{H}-\mathrm{NMR}$ and ${ }^{13} \mathrm{C}-\mathrm{NMR}$ spectroscopic data of compounds $1-2$ (in $\mathrm{CDCl}_{3}, 500 \mathrm{MHz}$ ) .

\begin{tabular}{|c|c|c|c|c|}
\hline \multirow{2}{*}{$\begin{array}{c}\text { Compounds } \\
\text { Position }\end{array}$} & \multicolumn{2}{|l|}{1} & \multicolumn{2}{|l|}{2} \\
\hline & ${ }^{1} H^{a}$ & ${ }^{13} \mathrm{C}$ & ${ }^{1} H^{a}$ & ${ }^{13} \mathrm{C}$ \\
\hline 1 & & 173.7 & $\begin{array}{l}4.21(\mathrm{dd}, J=11.7,5.7) \\
4.44(\mathrm{dd}, J=11.7,4.9)\end{array}$ & 65.4 \\
\hline 2 & & & & \\
\hline 3 & 5.90 (brs) & 94.7 & $\begin{array}{l}3.77(\mathrm{dd}, J=11.0,6.8) \\
3.89(\mathrm{dd}, J=11.0,3.6)\end{array}$ & 63.6 \\
\hline 4 & $2.59(\mathrm{dd}, J=10.9,2.1)$ & 50.0 & $2.70(\mathrm{ddd}, J=10.7,6.8,3.6)$ & 48.3 \\
\hline 5 & $3.32(\mathrm{~m})$ & 32.0 & $2.99(\mathrm{~m})$ & 37.0 \\
\hline $6 \alpha$ & $1.45(\mathrm{td}, J=10.8,3.4)$ & 42.0 & $1.65(\mathrm{td}, J=12.6,4.4)$ & 39.1 \\
\hline $6 \beta$ & $2.33(\mathrm{~m})$ & & $1.95(\mathrm{dd}, J=12.6,6.6)$ & \\
\hline 7 & $4.14(\mathrm{q}, J=3.4)$ & 75.0 & $4.24(\mathrm{q}, J=4.4)$ & 75.1 \\
\hline 8 & $2.30(\mathrm{~m})$ & 43.6 & $2.05(\mathrm{~m})$ & 42.4 \\
\hline 9 & $2.88(\mathrm{t}, J=10.9)$ & 46.2 & $2.22(\mathrm{~m})$ & 44.9 \\
\hline 10 & $1.28(\mathrm{~d}, J=7.0)$ & 14.4 & $1.13(\mathrm{~d}, J=7.2)$ & 14.2 \\
\hline 11 & & 170.6 & & 175.4 \\
\hline 11-OMe & $3.78(\mathrm{~s})$ & 52.7 & $3.67(\mathrm{~s})$ & 52.2 \\
\hline $1^{\prime}$ & & & & 130.4 \\
\hline $2^{\prime}$ & & & $8.00(\mathrm{~d}, J=7.5)$ & 129.7 \\
\hline $3^{\prime}$ & & & $7.45(\mathrm{t}, J=7.5)$ & 128.7 \\
\hline $4^{\prime}$ & & & $7.57(\mathrm{t}, J=7.5)$ & 133.3 \\
\hline $5^{\prime}$ & & & $7.45(\mathrm{t}, J=7.5)$ & 128.7 \\
\hline $6^{\prime}$ & & & $8.00(\mathrm{~d}, J=7.5)$ & 129.7 \\
\hline $7^{\prime}$ & & & & 166.8 \\
\hline
\end{tabular}

Compound 2 was obtained as a colorless oil. $[\alpha]_{\mathrm{D}}^{29}+16(c=0.10, \mathrm{MeOH})$. The molecular weight was determined by HR-ESI-MS, which showed an $[\mathrm{M}+\mathrm{Na}]^{+}$ion at an $\mathrm{m} / z$ of 359.1457 (calculated for $\left.\mathrm{C}_{18} \mathrm{H}_{24} \mathrm{O}_{6} \mathrm{Na} 359.1465\right)$, indicating seven degrees of unsaturation. The IR spectrum displayed the presence of hydroxyl $\left(3387 \mathrm{~cm}^{-1}\right)$, an ester carbonyl and conjugated ester carbonyl groups $\left(1720 \mathrm{~cm}^{-1}\right)$. The UV spectrum showed two $\lambda$ max absorption at $228 \mathrm{~nm}(\log \varepsilon 3.9)$ and $273 \mathrm{~nm}(\log \varepsilon 3.4)$. The ${ }^{1} \mathrm{H}$ and ${ }^{13} \mathrm{C}$ NMR data (Table 1) of this compound showed three moieties. The first moiety exhibited a hydroxyl methyl group at $\delta_{\mathrm{H}} 3.89(\mathrm{dd}, J=11.0,3.6, \mathrm{H}-3), \delta_{\mathrm{H}} 3.77(\mathrm{dd}, J=11.0,6.8, \mathrm{H}-3), \delta_{\mathrm{C}} 63.6(\mathrm{C}-3)$, a carbonylmethoxy group at $\delta_{\mathrm{H}} 3.67(\mathrm{~s}, 11-\mathrm{OMe}), \delta_{\mathrm{C}} 52.2(11-\mathrm{OMe}), \delta_{\mathrm{C}} 175.4(\mathrm{C}-11)$ together with a methine proton at $\delta_{\mathrm{H}} 2.70(\mathrm{ddd}, J=10.7,6.8,3.6, \mathrm{H}-4), \delta_{\mathrm{C}} 48.3(\mathrm{C}-4)$, these NMR signals evidenced 
that a methyl 3-hydroxypropanoate group with a substituent was located at the $\mathrm{C}-2$ position. The second moiety exhibited NMR signals at $\delta_{\mathrm{H}} 8.00\left(\mathrm{~d}, J=7.5, \mathrm{H}-2^{\prime} \& \mathrm{H}-6^{\prime}\right), \delta_{\mathrm{C}} 129.7\left(\mathrm{C}-2^{\prime} \& \mathrm{C}-6^{\prime}\right) ; \delta_{\mathrm{H}}$ $7.57\left(\mathrm{t}, J=7.5, \mathrm{H}-4^{\prime}\right), \delta_{\mathrm{C}} 133.3\left(\mathrm{C}-4^{\prime}\right)$ and $\delta_{\mathrm{H}} 7.45\left(\mathrm{t}, J=7.5, \mathrm{H}-3^{\prime} \& \mathrm{H}-5^{\prime}\right), \delta_{\mathrm{C}} 128.7\left(\mathrm{C}-3^{\prime} \& \mathrm{C}-5^{\prime}\right), \delta_{\mathrm{C}} 130.4$ $\left(\mathrm{C}-1^{\prime}\right)$ and $\delta_{\mathrm{C}} 166.8\left(\mathrm{C}-7^{\prime}\right)$ combined with methylene ester at $\delta_{\mathrm{H}} 4.44(\mathrm{dd}, J=11.7,4.9, \mathrm{H}-1), \delta_{\mathrm{H}} 4.21(\mathrm{dd}$, $J=11.7,5.7, \mathrm{H}-1), \delta_{\mathrm{C}} 65.4(\mathrm{C}-1)$. Then, UV and IR absorption data confirmed the second moiety being a methylenyl benzoate group. By compassion of 1D and 2D NMR spectra in Figure 2a and Table 1, the third moiety A ring of compound 2 was similar to the A ring of compound 1, being a cyclopentane iridoid moiety. Analysis of the COSY experiment (Figure 2a) permitted the establishment that $\mathrm{H}-4\left(\delta_{\mathrm{H}}\right.$ 2.70) in methyl 3-hydroxypropanoate moiety was correlated with $\mathrm{H}-5\left(\delta_{\mathrm{H}} 2.99\right)$ and HMBC correlation with C-5 $\left(\delta_{\mathrm{C}} 37.0\right) ; \mathrm{H}-6 \alpha\left(\delta_{\mathrm{H}} 1.65\right)$ was correlated with C-4 $\left(\delta_{\mathrm{C}} 48.3\right)$. The result proved that methyl 3-hydroxypropanoate with its C-2 position was located at C-5 of the A ring. Meanwhile, the H-1 of the methylenyl benzoate group was coupled with $\mathrm{H}-9$ in the A ring and also exhibited correlations with C-5 $\left(\delta_{C} 37.0\right), C-8\left(\delta_{C} 42.4\right)$ and C-9 $\left(\delta_{C} 44.9\right)$ in HMBC spectra. This evidence gave the result that methyl 3-hydroxypropanoate was positioned at C-9 of the A ring. The most stable conformer of compound $\mathbf{2}$ is shown in Figure $2 b$. There are two important points that can be determined from the NMR spectra: one in H-4 showing NOESY correlation with $\mathrm{H}-6 \alpha$ and second proved the coupling constant between $\mathrm{H}-4$ and $\mathrm{H}-5$ with $J=10.7$, which showed a larger coupling constant, except that it was anti-coplanar. The proposed biosynthetic pathway is illustrated by positions 1 and 2 of dihydrologanin (21) being hydrolyzed to compound 22,22 being reduced to compound 23 and finally, compound 23 being benzylated to compound $\mathbf{2}$ as shown in Figure 3. Accordingly, compound $\mathbf{2}$ was established as depicted and given the name neonanin $\mathrm{D}$.

(a)

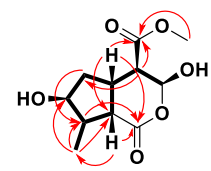

(b)

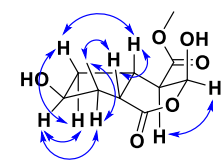

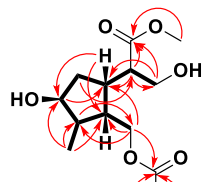
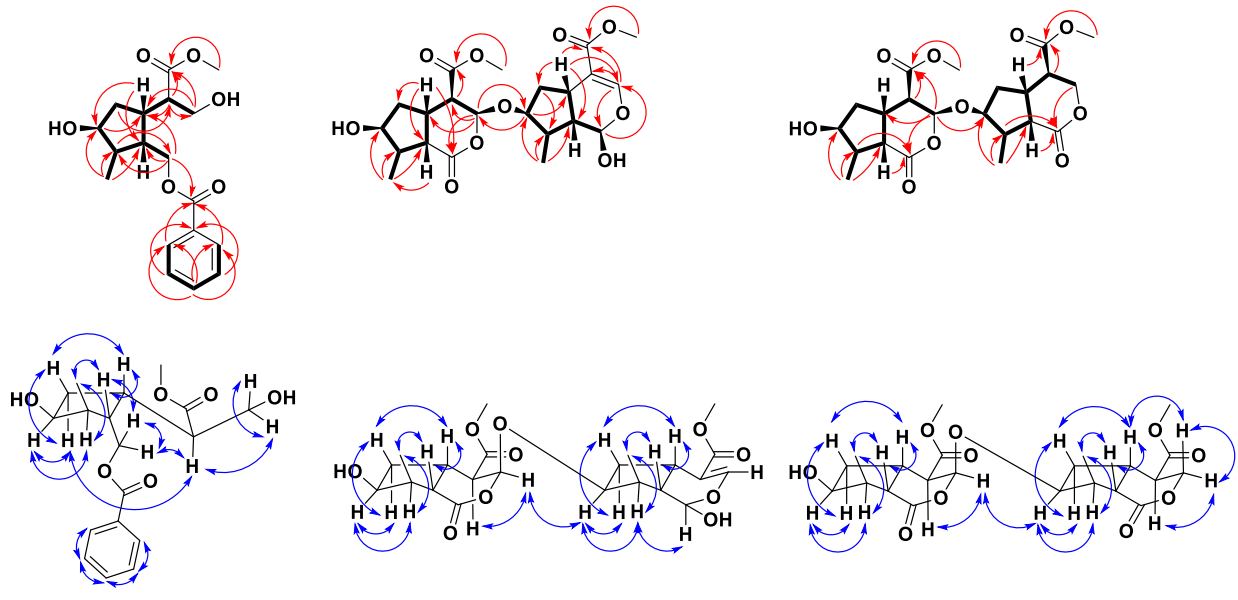

3

Figure 2. (a) Significant COSY (bold line) correlations and (HMBC) $(\longrightarrow$ ) correlations for compounds 1-4; (b). Significant NOESY $(\longleftrightarrow)$ correlations of compounds 1-4.

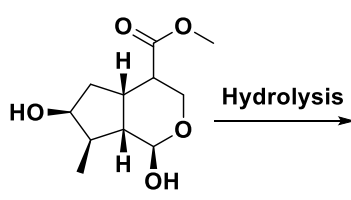

21<smiles>COC(=O)[C@H]1CC(O)C(C)[C@H]1C=O</smiles>

22<smiles>COC(=O)[C@H]1C[C@@H](O)[C@H](C)C1(CO)CO</smiles>

23

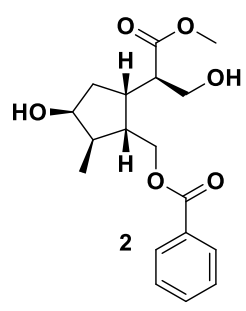

Figure 3. Proposed biosynthetic sequence of neonanin D (2).

Compound 3 was obtained as a colorless oil. $[\alpha]_{\mathrm{D}}^{28}+32(\mathrm{c}=0.07, \mathrm{MeOH})$. The molecular weight was determined by HR-ESI-MS, which showed an $[\mathrm{M}-\mathrm{H}]^{+}$ion at $\mathrm{m} / z$ of 453.17553 (calculated for $\mathrm{C}_{22} \mathrm{H}_{29} \mathrm{O}_{10} 453.17752$ ), indicating eight degrees of unsaturation. The IR spectrum displayed the 
presence of hydroxyl $\left(3387 \mathrm{~cm}^{-\mathrm{h}}\right)$ and ester lactone and conjugated ester carbonyl groups $\left(1722 \mathrm{~cm}^{-1}\right)$. The UV spectrum showed the $\lambda_{\max }$ absorption at $236 \mathrm{~nm}\left(\log \varepsilon\right.$ 3.6). The ${ }^{1} \mathrm{H}$ and ${ }^{13} \mathrm{C}$ spectra of this compound (Table 2) exhibited two iridoid moieties: units A and B. The proton and carbon signals of unit A showed similar chemical shifts compared to compound 1 by ${ }^{1} \mathrm{H}-\mathrm{NMR},{ }^{13} \mathrm{C}-\mathrm{NMR}$ and HSQC spectrums, which indicated that structure of unit A was neonanin C. Among them, the chemical shift at position 3 in the compound 3 was different compared to compound 1. The proton H-3 upshifted to $\delta_{\mathrm{H}} 5.63(\mathrm{~d}, J=2.6)$; carbon signal downshifted to $\delta_{\mathrm{C}} 98.3(\mathrm{C}-3)$, this suggests that an alkoxy group is connected in position 3 instead of a hydroxyl group. For unit $B$, the ${ }^{1} \mathrm{H}-\mathrm{NMR}$ spectrum indicated the presence of an olefinic proton at $\delta_{\mathrm{H}} 7.40\left(\mathrm{~d}, J=2.1, \mathrm{H}-3^{\prime}\right)$, an hemiacetal proton at $\delta_{\mathrm{H}} 4.93(\mathrm{~d}, J=5.6$, $\left.\mathrm{H}-1^{\prime}\right)$, one oxymethine at $\delta_{\mathrm{H}} 4.20\left(\mathrm{~m}, \mathrm{H}-7^{\prime}\right)$, a carbonylmethoxy group at $\delta_{\mathrm{H}} 3.71\left(\mathrm{~s}, 11^{\prime}\right.$-OMe) and a doublet methyl group at $\delta_{\mathrm{H}} 1.08\left(\mathrm{~d}, J=6.9, \mathrm{H}-10^{\prime}\right)$. Moreover, the ${ }^{13} \mathrm{C}-\mathrm{NMR}$ spectrum in combination with IR and UV spectra suggested the existence of an $\alpha, \beta$-unsaturated ester carbon at $\delta_{C} 167.6\left(C-11^{\prime}\right)$, the signals at $\delta_{C} 151.5\left(\mathrm{C}-3^{\prime}\right), \delta_{C} 111.8\left(\mathrm{C}-4^{\prime}\right)$ for double bonds and $\beta$-hydroxy pyranose anomeric carbon at $\delta_{C} 95.7\left(\mathrm{C}-1^{\prime}\right)$, one methoxy carbon at $\delta_{C} 51.4\left(11^{\prime}-\mathrm{OMe}\right)$ and methyl at $\delta_{\mathrm{C}} 13.9\left(\mathrm{C}-10^{\prime}\right)$ can be observable in this moiety. Along with the main protons correlated in the COSY spectrum (Figure 2a) from ring $C$, the existence of a cyclopentane skeleton is suggested. The main HMBC correlations (Figure 2a) of the carbonylmethoxy group were represented by the $\alpha, \beta$-unsaturated bond from ring D by $11^{\prime}-\mathrm{OMe}\left(\delta_{\mathrm{H}} 3.71\right)$ to $\mathrm{C}-11^{\prime}\left(\delta_{\mathrm{C}} 167.6\right)$ and $\mathrm{H}-3^{\prime}\left(\delta_{\mathrm{H}} 7.40\right)$ to $\mathrm{C}-1^{\prime}\left(\delta_{\mathrm{C}} 95.7\right), \mathrm{C}-4^{\prime}\left(\delta_{\mathrm{C}} 111.8\right), \mathrm{C}-11^{\prime}\left(\delta_{\mathrm{C}}\right.$ 167.6). Ring $\mathrm{D}$ linked with ring $\mathrm{C}$ in unit $\mathrm{B}$ was confirmed as such $\mathrm{H}-1^{\prime}\left(\delta_{\mathrm{H}} 4.93\right)$ to $\mathrm{C}-3^{\prime}\left(\delta_{\mathrm{C}} 151.5\right), \mathrm{C}-5^{\prime}$ $\left(\delta_{\mathrm{C}} 31.7\right) ; \mathrm{H}-5^{\prime}\left(\delta_{\mathrm{H}} 2.93\right)$ to $\mathrm{C}-3^{\prime}\left(\delta_{\mathrm{C}} 151.5\right), \mathrm{C}-4^{\prime}\left(\delta_{\mathrm{C}} 111.8\right)$. This unit $\mathrm{B}$ is almost identical to loganetin (Compound 3a), which was isolated in our previous study. The HMBC showed that these two units were linked by an O-linkage, as it showed correlations between $\mathrm{H}-3\left(\delta_{\mathrm{H}} 5.63\right)$ in unit A to C-7' $\left(\delta_{\mathrm{C}} 80.4\right)$ in unit $\mathrm{B}$ and $\mathrm{H}-\mathrm{7}^{\prime}\left(\delta_{\mathrm{H}} 4.20\right)$ to $\mathrm{C}-3\left(\delta_{\mathrm{C}} 98.3\right)$, therefore, this suggests that compound 3 is a bis-iridoid with a C-3-O-C-7' ether linkage-type structure. In NOESY correlation results, unit A suggested a stereochemistry similar to neonanin C. Protons from ring $C$ also showed the same NOESY results as those of ring A. In the literature review, the reports present the $\alpha$-configuration at proton $\mathrm{H}-1^{\prime}$ of the loganetin moiety [31]. NOESY cross peak between $\mathrm{H}-3\left(\delta_{\mathrm{H}} 5.63\right)$ to $\mathrm{H}-7^{\prime}\left(\delta_{\mathrm{H}} 4.20\right)$ confirmed that these two protons were located in $\alpha$ form and gave this compound the most stable conformation, as shown in Figure $2 \mathrm{~b}$. This correlation supported the above stereostructure configuration. Accordingly, the structure of compound 3 was named reticunin A.

Compound 4 was obtained as colorless oil. $[\alpha]_{\mathrm{D}}^{28}+27(c=0.05, \mathrm{MeOH})$. The molecular weight was established by HR-ESI-MS, which showed an [M - H] ${ }^{+}$ion at $m / z$ of 453.1767 (calculated for $\left.\mathrm{C}_{22} \mathrm{H}_{29} \mathrm{O}_{10} 453.1755\right)$, indicating eight degrees of unsaturation. The IR spectrum displayed the presence of hydroxyl $\left(3414 \mathrm{~cm}^{-1}\right)$ and $\gamma$-lactone $\left(1734 \mathrm{~cm}^{-1}\right)$ groups. Comparison of ${ }^{1} \mathrm{H}$ and ${ }^{13} \mathrm{C}$-NMR values and analysis of the 2D spectrum showed that 3 and 4 contained the same skeleton and unit A moiety; the difference between 3 and 4 should be the iridoid derivative moiety located at unit $\mathrm{B}$. On the main ${ }^{1} \mathrm{H}$ and ${ }^{13} \mathrm{C}-\mathrm{NMR}$ spectrum (Table 2) of unit $\mathrm{B}$, one $\mathrm{CH}_{2} \mathrm{OR}$ group at $\delta_{\mathrm{H}} 4.25\left(\mathrm{dd}, J=11.3,9.8, \mathrm{H}-3^{\prime} \beta\right)$ and $\delta_{\mathrm{H}} 4.45\left(\mathrm{dd}, J=11.3,3.3, \mathrm{H}-3^{\prime} \alpha\right) ; \delta_{\mathrm{C}} 67.5\left(\mathrm{C}-3^{\prime}\right)$, one oxymethine at $\delta_{\mathrm{H}} 4.23\left(\mathrm{~m}, \mathrm{H}-7^{\prime}\right) ; \delta_{\mathrm{C}} 81.0\left(\mathrm{C}-7^{\prime}\right)$, one carbonylmethoxy group at $\delta_{\mathrm{H}} 3.74\left(\mathrm{~s}, 11^{\prime}-\mathrm{OMe}\right) ; \delta_{\mathrm{C}} 52.6\left(11^{\prime}\right.$-OMe) and one doublet methyl group at $\delta_{\mathrm{H}} 1.19\left(\mathrm{~d}, J 6.8, \mathrm{H}-10^{\prime}\right) ; \delta_{\mathrm{C}} 14.7\left(\mathrm{C}-10^{\prime}\right)$ were shown. Besides, secondary carbon $\delta_{\mathrm{C}} 37.3\left(\mathrm{C}-6^{\prime}\right)$ and tertiary carbon $\delta_{\mathrm{C}} 37.4\left(\mathrm{C}-5^{\prime}\right)$ could surely identified by DEPT. The cyclopentanyl moiety of unit B was also assigned by using COSY experiment (Figure 2a). The connectivity between A and B units was found to be an $O$-linkage between position 3 to position $7^{\prime}$ by $\delta_{\mathrm{H}} 5.59(\mathrm{H}-3)$ of unit A correlated to carbon $\delta_{\mathrm{C}} 81.0\left(\mathrm{C}-7^{\prime}\right)$ in unit B from HMBC spectrum (Figure 2a). The position of two carbonyl carbon $\delta_{\mathrm{C}} 171.2\left(\mathrm{C}-11^{\prime}\right)$ and $\delta_{\mathrm{C}} 173.3\left(\mathrm{C}-1^{\prime}\right)$ were also deduced by the HMBC correlation form $\delta_{\mathrm{H}} 4.45\left(\mathrm{H}-3^{\prime} \alpha\right)$,

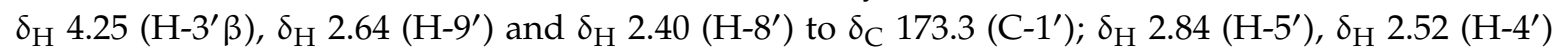
and $\delta_{\mathrm{H}} 3.74\left(11^{\prime}-\mathrm{OMe}\right)$ to $\delta_{\mathrm{C}} 171.2\left(\mathrm{C}-11^{\prime}\right)$ in ring $\mathrm{D}$. Thus, the moiety of unit $\mathrm{B}$ could be compared to literature and assigned as 6-hydroxy-7-methyl-1-oxo-4-carbomethoxyoctahydrocyclopenta[c]pyran (compound 4a) [32]. The relative configuration of unit A of 4 was confirmed with 3 and got the same correlation results. The NOESY spectrum of ring $\mathrm{C}$ also exhibited a similar cross peak signal to 3 and 
the coupling constants from ring $\mathrm{D}, J_{3^{\prime} \beta, 4^{\prime}}=9.8$ and $J_{3^{\prime} \alpha, 4^{\prime}}=3.3$ suggested that the carbonylmethoxy group and $\mathrm{H}-3^{\prime} \beta$ were in $\beta$-form, while $\mathrm{H}-4^{\prime}$ and $\mathrm{H}-3^{\prime} \alpha$ were in $\alpha$-form. Finally, $\mathrm{H}-3\left(\delta_{\mathrm{H}} 5.59\right)$ was correlated to $\mathrm{H}^{-7^{\prime}}\left(\delta_{\mathrm{H}} 4.23\right)$ located in $\alpha$ form are the most stable conformation for compound 4 . Thus, the structure of compound 4 was concluded to be reticunin B.

Table 2. ${ }^{1} \mathrm{H}-\mathrm{NMR}$ and ${ }^{13} \mathrm{C}-\mathrm{NMR}$ spectroscopic data of compounds 3-4 (in $\mathrm{CDCl}_{3}, 500 \mathrm{MHz}$ ) ${ }^{\mathrm{a}}$.

\begin{tabular}{|c|c|c|c|c|c|}
\hline \multirow{2}{*}{$\begin{array}{c}\text { Compound } \\
\text { Position }\end{array}$} & \multicolumn{2}{|l|}{3} & \multirow{2}{*}{$\begin{array}{c}\text { Compound } \\
\text { Position }\end{array}$} & \multicolumn{2}{|l|}{4} \\
\hline & ${ }^{1} \mathrm{H}^{\mathrm{a}}$ & ${ }^{13} \mathrm{C}$ & & ${ }^{1} \mathbf{H}^{\mathrm{a}}$ & ${ }^{13} \mathrm{C}$ \\
\hline 1 & & 174.1 & 1 & & 173.5 \\
\hline 2 & & & 2 & & \\
\hline 3 & $5.63(\mathrm{~d}, J=2.6)$ & 98.3 & 3 & $5.59(\mathrm{~d}, J=2.5)$ & 98.1 \\
\hline 4 & $2.60(\mathrm{dd}, J=11.6,2.6)$ & 50.1 & 4 & $2.59(\mathrm{dd}, J=11.6,2.5)$ & 50.0 \\
\hline 5 & $3.31(\mathrm{~m})$ & 32.0 & 5 & $3.33(\mathrm{~m})$ & 32.1 \\
\hline $6 \alpha$ & $1.42(\mathrm{~m})$ & 42.3 & $6 \alpha$ & $1.42(\mathrm{~m})$ & 42.3 \\
\hline $6 \beta$ & $2.34(\mathrm{dd}, J=13.6,7.6)$ & & $6 \beta$ & $2.35(\mathrm{dd}, J=13.8,7.6)$ & \\
\hline 7 & $4.12(\mathrm{~m})$ & 75.1 & 7 & $4.13(\mathrm{~m})$ & 75.1 \\
\hline 8 & $2.27(\mathrm{~m})$ & 43.7 & 8 & $2.29(\mathrm{~m})$ & 43.6 \\
\hline 9 & $\begin{array}{c}2.79(\mathrm{dd}, J=11.6 \\
10.1)\end{array}$ & 46.2 & 9 & $\begin{array}{c}2.77(\mathrm{dd}, J=11.6 \\
10.1)\end{array}$ & 46.1 \\
\hline 10 & $1.29(\mathrm{~d}, J=6.9)$ & 14.6 & 10 & $1.29(\mathrm{~d}, J=6.8)$ & 14.6 \\
\hline 11 & & 169.7 & 11 & & 169.8 \\
\hline $11-\mathrm{OMe}$ & $3.82(\mathrm{~s})$ & 52.7 & $11-\mathrm{OMe}$ & $3.77, \mathrm{~s}$ & 52.6 \\
\hline $1^{\prime}$ & $4.93(\mathrm{~d}, J=5.6)$ & 95.7 & $1^{\prime}$ & & 173.3 \\
\hline $2^{\prime}$ & & & $2^{\prime}$ & & \\
\hline $3^{\prime}$ & $7.40(\mathrm{~d}, J=1.2)$ & 151.5 & $3^{\prime} \alpha$ & $4.45(\mathrm{dd}, J=11.3,3.3)$ & 67.5 \\
\hline & & & $3^{\prime} \beta$ & $4.25(\mathrm{dd}, J=11.3,9.8)$ & \\
\hline $4^{\prime}$ & & 111.8 & $4^{\prime}$ & $2.52(\mathrm{td}, J=9.8,3.3)$ & 46.1 \\
\hline $5^{\prime}$ & $2.93(\mathrm{q}, J=8.5)$ & 31.7 & $5^{\prime}$ & $2.84(\mathrm{~m})$ & 37.4 \\
\hline $6^{\prime} \alpha$ & $1.37(\mathrm{~m})$ & 38.2 & $6^{\prime} \alpha$ & $1.37(\mathrm{~m})$ & 37.3 \\
\hline $6^{\prime} \beta$ & $2.42(\mathrm{dd}, J=14.3,7.4)$ & & $6^{\prime} \beta$ & $2.30(\mathrm{~m})$ & \\
\hline $7^{\prime}$ & $4.20(\mathrm{~m})$ & 80.4 & $7^{\prime}$ & $4.23(\mathrm{~m})$ & 81.0 \\
\hline $8^{\prime}$ & $1.97(\mathrm{~m})$ & 40.9 & $8^{\prime}$ & $2.40(\mathrm{~m})$ & 43.9 \\
\hline $9^{\prime}$ & $1.89(\mathrm{td}, J=8.5,5.6)$ & 46.8 & $9^{\prime}$ & $2.64(\mathrm{dd}, J=11.2,9.6)$ & 46.2 \\
\hline $10^{\prime}$ & $1.08(\mathrm{~d}, J=6.9)$ & 13.9 & $10^{\prime}$ & $1.19(\mathrm{~d}, J=6.8)$ & 14.7 \\
\hline $11^{\prime}$ & & 167.6 & $11^{\prime}$ & & 171.2 \\
\hline $11^{\prime}-\mathrm{OMe}$ & $3.71(\mathrm{~s})$ & 51.4 & $11^{\prime}-\mathrm{OMe}$ & $3.74(\mathrm{~s})$ & 52.6 \\
\hline
\end{tabular}

${ }^{a}$ The chemical shifts are expressed in $\delta$ ppm. The coupling constants $(J)$ are expressed in $\mathrm{Hz}$.

\subsection{In-Vitro Cell Viability and NO Inhibition Activity of the Compounds 1-20}

In this study, nine iridoids (1-9), three lignans (10-12) and eight aromatic rings (13-20) were exposed to different concentrations $(6.25,12.5,25,50$ and $100 \mu \mathrm{g} / \mathrm{mL})$ for testing their cell viability, while the control group was only stimulated by LPS. There were no obvious effects of all compounds on cell viability determined by MTT assay. Furthermore, twenty compounds were tested for the inhibitory effects on NO production by LPS-stimulated RAW 264.7 cells. As shown in Table 3, Isoboonein (7), (+)-medioresinol (12), protocatechuic acid (14) and trans-caffeic acid (15) found to have $\mathrm{IC}_{50}$ values compared with positive drug (indomethacin) at $86.27 \pm 3.45(p<0.001) ; 76.18 \pm 2.42(p<0.001)$; $72.91 \pm 4.97(p<0.005)$ and $95.16 \pm 1.20 \mu \mathrm{g} / \mathrm{mL}(p<0.001)$, respectively. Syringaresinol (10) exhibited better $\mathrm{IC}_{50}$ values at $9.18 \pm 1.90 \mu \mathrm{g} / \mathrm{mL}(p<0.001)$ compared with indomethacin. The cell viability $(\%)$ and nitric oxide production (\%) in each concentration of these five compounds were presented in Figure S32. These compounds may possibly contribute to the NO inhibition activity of N. reticulata. Indomethacin was used as a positive control in this study, which is a clinically effective anti-inflammatory medication that inhibits COX- 1 and COX-2 and reduces prostaglandin synthesis [33]. The $\mathrm{IC}_{50}$ value of indomethacin was $46.71 \pm 3.14 \mu \mathrm{g} / \mathrm{mL}$. From literature investigation, $\mathrm{NO}$ which was produced by nitric oxide synthase (iNOS) was involved in the pro-inflammatory responses [34], besides, COX-2, TNF- $\alpha$ 
and IL-1 $\beta$, these pro-inflammatory mediators also were regulated by activation of the transcription factor NF-KB [35]. The results of LPS stimulated RAW264.7 cells would cause the phosphorylation of p38 MAPK and JNK1/2, leading NF-kB activation demonstrated by Elke Cario in 2000 [36]. Also, oxidative stress was the reason to activate a variety of mediators in inflammatory progress [37]. Compound 10 could interference with JNK and p38 phosphorylation to down-regulating NF- $\mathrm{kB}$ expression and reducing levels of iNOS, COX-2 and TNF- $\alpha$ [38] and demonstrated as anti-oxidative by DPPH and hydroxyl radical scavenging assay [39]. Compound $\mathbf{1 4}$ may inhibit the expression of TNF- $\alpha$, IL- $\beta$ and COX-2 by regulating NF- $\mathrm{kB}$ [35], compound 15 could mediated NO production by down-regulating NF-kB, p38 MAP kinase and JNK1/2 [40]. These two compounds could be anti-oxidative materials by confirmed with DPPH and ABTS radical scavenging assay [41]. The detailed mechanism of (+)-medioresinol (12) is still unclear but there has some reference indicated that this compound was found to have antioxidant [42] and inhibited NO production in LPS-stimulated RAW cells [43]. Herein, inhibition of these mediators production or scavenging oxidative stress abilities will be the main reason for compounds to have anti-inflammatory properties. In our knowledge, isoboonein (7) has been shown to have antibacterial and antitumor activity in previous studies [44], while anti-inflammatory activity is still unknown. Therefore, this is the first study to investigate the preliminary anti-inflammatory activity of isoboonein by testing NO inhibition ability. Our work only presented very preliminary cell viability and NO inhibition activity. The anti-inflammatory mechanisms of compound 10, $\mathbf{1 4}$ and $\mathbf{1 5}$ have been careful described in the literatures. In future works, the experiments to test NF-kB, TNF- $\alpha$, IL-1 $\beta$, IL-6, MAPK and PGE2 regulated abilities of compound 7 and 12 and also antioxidant ability of compound 7 are needed. These assays can increase the two compounds' credibility of anti-inflammatory and also explore the mechanisms.

Table 3. In vitro inhibition of nitric oxide production of compounds $\mathbf{1 - 2 0}$ on NO production by LPS stimulated in RAW264.7 cells.

\begin{tabular}{cccccc}
\hline Compounds & $\mathrm{CC}_{\mathbf{5 0}}(\mu \mathrm{g} / \mathbf{m L})^{\mathrm{a}}$ & $\mathrm{IC}_{\mathbf{5 0}}(\boldsymbol{\mu g} / \mathbf{m L})^{\mathrm{a}}$ & Compounds & $\mathrm{CC}_{\mathbf{5 0}}(\boldsymbol{\mu g} / \mathbf{m L})^{\mathrm{a}}$ & $\mathrm{IC}_{\mathbf{5 0}}(\boldsymbol{\mu g} / \mathbf{m L})^{\mathrm{a}}$ \\
\hline $\mathbf{1}$ & $>100^{\mathrm{b}}$ & $>100$ & $\mathbf{1 1}$ & $>100^{\mathrm{b}}$ & $>100$ \\
$\mathbf{2}$ & $>100^{\mathrm{b}}$ & $>100$ & $\mathbf{1 2}$ & $>100^{\mathrm{b}}$ & $76.18 \pm 2.42^{* * *}$ \\
$\mathbf{3}$ & $>100^{\mathrm{b}}$ & $>100$ & $\mathbf{1 3}$ & $>100^{\mathrm{b}}$ & $>100^{*}$ \\
$\mathbf{4}$ & $>100^{\mathrm{b}}$ & $>100$ & $\mathbf{1 4}$ & $>100^{\mathrm{b}}$ & $72.91 \pm 4.97^{* *}$ \\
$\mathbf{5}$ & $>100^{\mathrm{b}}$ & $>100$ & $\mathbf{1 5}$ & $>100^{\mathrm{b}}$ & $95.16 \pm 1.20^{* * *}$ \\
$\mathbf{6}$ & $>100^{\mathrm{b}}$ & $>100$ & $\mathbf{1 6}$ & $>100^{\mathrm{b}}$ & $>100$ \\
$\mathbf{7}$ & $>100^{\mathrm{b}}$ & $86.27^{\mathrm{a}} \pm 3.45^{* * *}$ & $\mathbf{1 7}$ & $>100^{\mathrm{b}}$ & $>100$ \\
$\mathbf{8}$ & $>100^{\mathrm{b}}$ & $>100$ & $\mathbf{1 8}$ & $>100^{\mathrm{b}}$ & $>100$ \\
$\mathbf{9}$ & $>100^{\mathrm{b}}$ & $>100$ & $\mathbf{1 9}$ & $>100^{\mathrm{b}}$ & $>100$ \\
$\mathbf{1 0}$ & $>100^{\mathrm{b}}$ & $9.18 \pm 1.90^{* * *}$ & $\mathbf{2 0}$ & $>100^{\mathrm{b}}$ & $>100$ \\
$\mathbf{1 1}$ & $>100^{\mathrm{b}}$ & $>100$ & Indomethacin & $>100^{\mathrm{b}}$ & $46.71 \pm 3.14$ \\
\hline
\end{tabular}

${ }^{\mathrm{a}}$ The values shown are the mean $\pm \mathrm{SD}$ of data from three independent experiments; ${ }^{\mathrm{b}} \mathrm{CC}_{50}$ could not be obtained because of a cell survival rate $>88 \%$ at $100-6.25 \mu \mathrm{g} / \mathrm{mL} ;{ }^{* *} p<0.01,{ }^{* * *} p<0.001$ vs Indomethacin.

\section{Materials and Methods}

\subsection{General}

The optical rotation data were measured in $\mathrm{MeOH}$ with a Jasco P-2000 Polarimeter (JASCO Inc., Tokyo, Japan). The infrared spectra were acquired on Shimadzu IR Affinity-1S Fourier Transform Infrared Spectrophotometer. The UV spectra were obtained from LAMBDA 265 UV/Vis Spectrophotometer (PerkinElmer Inc., Waltham, MA, USA). The 1D and 2D-NMR spectra were recorded with a Bruker Avance 500 FT-NMR spectrometer (Bruker Inc., Bremen, Germany). The HR-ESI-MS data were generated at the Mass Spectrometry Laboratory of the Chung Hsing University with a Thermo LTQ Orbitrap XL TM Hybrid Ion Trap-Orbitrap Mass Spectrometer (Thermo Scientific Inc., Waltham, MA, USA). Column chromatography was performed using LiChroCART Si $5 \mu \mathrm{M}$ gel (Merck, Darmstadt, Germany) and Sephadex LH-20 (GE Healthcare Life Sciences Inc., Marlborough, MA, USA). 
The TLC (thin-layer chromatography) analysis was carried out using aluminum pre-coated Si plates (Silica Gel 60 F-254; Merck). The spots were visualized using a UV lamp at $\lambda=254 \mathrm{~nm}$ and detected by spraying with $10 \% \mathrm{H}_{2} \mathrm{SO}_{4}$ alcohol solution and heating at $125^{\circ} \mathrm{C}$. Semi-preparative HPLC was performed using a normal phase column (Luna $5 \mu \mathrm{m}$ Silica $100 \AA$, $250 \times 10 \mathrm{~mm}$; Phenomenex Inc.) on a Precision Instruments IOTA 2 Refractive Index Detector system.

\subsection{Chemicals}

The solvents used to open the column isolation (Silica gel and Sephadex LH 20 gel column) in the study, such as $n$-hexane, dichloromethane, chloroform, ethyl acetate, acetone and methanol, were of ACS grade. The $n$-hexane, dichloromethane, chloroform, ethyl acetate and acetone used for HPLC isolation, which was of HPLC grade and the deuterated solvents for NMR measurement $\left(\mathrm{CDCl}_{3}\right.$ and $\left.\mathrm{CD}_{3} \mathrm{COCD}_{3}\right)$ were purchased from the branch of Merck in Taipei, MTT (3-(4,5-dimethylthiazol-2-yl)-2,5-diphenyltetrazolium bromide), LPS (Escherichia coli 055:B5), indomethacin and other chemicals were purchased from Sigma Chemical Co. (St. Louis, MO, USA). Minimum essential media (MEM), trypsin-EDTA, fetal bovine serum (FBS), penicillin/streptomycin, non-essential amino acids (NEAA) and sodium pyruvate were obtained from Gibco (BRL life Technologies, Grand Island, NY, USA).

\subsection{Plant Material}

The stems of Neonauclea reticulata were collected from Nan Ren Mountain, Pingtung, Taiwan, in August 2012 and identified by Yau Lun Kuo (Professor, Department of Forestry, National Pingtung University of Science and Technology, Pingtung, Taiwan). A voucher specimen (CMU-NR-201208) was deposited at the School of Chinese Pharmaceutical Sciences and Chinese Medicine Resources.

\subsection{Extraction and Isolation}

The air-dried stems of Neonauclea reticulata $(9.0 \mathrm{~kg}$ ) were extracted with $\mathrm{MeOH}$ (50 L each for seven days) three times at room temperature. The extracts were filtered; the filtrate was evaporated under reduced pressure at $35{ }^{\circ} \mathrm{C}$ with a rotavapor to obtain the $\mathrm{MeOH}$ extracts $(365 \mathrm{~g})$. The $\mathrm{MeOH}$ extracts were suspended in distilled water and successively solvent partitioned with ethyl acetate and $n$-buthanol (1:1,v/v), yielding soluble fraction of ethyl acetate (EtOAc) (100 g), n-buthanol (BuOH) (152 $\mathrm{g}$ ) and water $\left(\mathrm{H}_{2} \mathrm{O}\right)(98 \mathrm{~g})$. The EtOAc solution fraction was to passage over by column chromatography (CC) (2.0 kg of $\mathrm{SiO}_{2}, 70-230$ mesh; n-hexane/EtOAc/methanol gradient) to allow 32 fractions, Fr.1-Fr.32.

Fr.22 (4.6 g) was re-separated by sephadex $\mathrm{LH}-20$ (250 g; $\mathrm{CHCl}_{3} / \mathrm{MeOH}=3 / 7$ ) to produce 11 fractions. Fr.22-6 (1.47 g) was re-separated by silica gel column chromatography (30 g of $\mathrm{SiO}_{2}$, 70-230 mesh; $\mathrm{CHCl}_{3} /$ EtOAc (25\%)) and to obtain 21 subfractions, Fr.22-6-10 (56.7 mg) purified by normal-phase HPLC ( $n$-hexane/acetone $(40 \%)$ ) to afford pure compound $7\left(14.6 \mathrm{mg}, t_{\mathrm{R}}=26 \mathrm{~min}\right)$; Fr.22-6-13 (725.69 mg) was further purified was further purified through a silica gel column $(2 \times 16.5 \mathrm{~cm})$ to obtain 8 subfractions. Fr.22-6-13-3 (17.6 mg) purified by HPLC ( $n$-hexane/acetone $(40 \%)$ ) to afford pure compound $6\left(1.1 \mathrm{mg}, t_{\mathrm{R}}=13 \mathrm{~min}\right)$ and $1\left(1.4 \mathrm{mg}, t_{\mathrm{R}}=24 \mathrm{~min}\right)$. Fr.22-7 $(275 \mathrm{mg})$ was purified by HPLC $\left(\mathrm{CHCl}_{3} /\right.$ EtOAc $\left.(40 \%)\right)$ to obtain 13 subfractions. Fr.22-7-3 (15.13 mg) was purified by HPLC (n-hexane/acetone $(40 \%))$ to afford pure compounds $11\left(1.5 \mathrm{mg}, t_{\mathrm{R}}=13 \mathrm{~min}\right), \mathbf{1 3}\left(2.5 \mathrm{mg}, t_{\mathrm{R}}=17 \mathrm{~min}\right)$ and $5\left(7.8 \mathrm{mg}, t_{\mathrm{R}}=18 \mathrm{~min}\right)$. Fr.22-7 $(275.0 \mathrm{mg})$ was re-separated by silica gel column chromatography (5.5 $\mathrm{g}$ of $\mathrm{SiO}_{2}, 70-230$ mesh; $\mathrm{CHCl}_{3}$ /acetone (20\%)) to afford 14 fractions. Fr.22-7-8 (7.4 mg) was purified by normal phase HPLC ( $n$-hexane/acetone (30\%)) to form pure compounds $10\left(3.2 \mathrm{mg}, t_{\mathrm{R}}=15 \mathrm{~min}\right)$ and $11\left(2.0 \mathrm{mg}, t_{\mathrm{R}}=26 \mathrm{~min}\right)$. Fr.22-9 $(141.2 \mathrm{mg})$ was separated by normal phase HPLC $\left(\mathrm{CHCl}_{3} /\right.$ acetone $\left.(20 \%)\right)$ to afford 12 subfractions. Fr.22-9 (141.2 mg) was purified by normal phase HPLC ( $n$-hexane/acetone $(40 \%)$, resulting in pure compounds $19\left(2.2 \mathrm{mg}, t_{\mathrm{R}}=4 \mathrm{~min}\right), 18\left(12 \mathrm{mg}, t_{\mathrm{R}}=13 \mathrm{~min}\right), 16(3 \mathrm{mg}$, $\left.t_{\mathrm{R}}=14 \mathrm{~min}\right)$ and $17\left(2.5 \mathrm{mg}, t_{\mathrm{R}}=16 \mathrm{~min}\right)$. Fr.22-11(11.5 mg) was purified by normal phase HPLC $\left(\mathrm{CHCl}_{3}\right.$ /acetone $(22 \%)$ and afford compound $14\left(2.3 \mathrm{mg}, t_{\mathrm{R}}=16 \mathrm{~min}\right)$. 
Fr.23 (1.2 g) was re-separated by sephadex $\mathrm{LH}-20\left(140 \mathrm{~g} ; \mathrm{CHCl}_{3} / \mathrm{MeOH}=3 / 7\right)$ to afford 6 fractions, Fr.23-3 (832.68 mg) was re-separated by silica gel column chromatography (16 g of $\mathrm{SiO}_{2}, 70-230$ mesh; $\mathrm{CHCl}_{3} /$ EtOAc (25\%)) to afford 13 subfractions. Fr.23-3-1 (34 mg) was purified by normal phase HPLC ( $n$-hexane/acetone (40\%), resulting in pure compounds $4\left(0.8 \mathrm{mg}, t_{\mathrm{R}}=6 \mathrm{~min}\right), 3\left(2 \mathrm{mg}, t_{\mathrm{R}}=7 \mathrm{~min}\right)$, $20\left(1.9 \mathrm{mg}, t_{\mathrm{R}}=35 \mathrm{~min}\right)$ and $10\left(3.7 \mathrm{mg}, t_{\mathrm{R}}=44 \mathrm{~min}\right)$. Fr.23-4 $(48.5 \mathrm{mg})$ was re-separated by silica gel column chromatography ( $970 \mathrm{mg}$ of $\mathrm{SiO}_{2}, 70-230$ mesh; $\mathrm{CHCl}_{3}$ /acetone (45\%)) to afford 2 subfractions. Fr.23-4-1 (37.8 mg) was purified by normal phase HPLC $\left(\mathrm{CHCl}_{3} /\right.$ acetone $(45 \%)$ to get compounds 15 $\left(2 \mathrm{mg}, t_{\mathrm{R}}=21 \mathrm{~min}\right)$ and $2\left(1.2 \mathrm{mg}, t_{\mathrm{R}}=40 \mathrm{~min}\right)$.

Fr.25 (6.6 g) was re-separated by sephadex $\mathrm{LH}-20(300 \mathrm{~g} ; \mathrm{CHCl} / \mathrm{MeOH}=3 / 7)$ to produce 26 fractions. Fr.25-14 (934.5 mg) was re-separated by silica gel column chromatography (1.9 $\mathrm{g}$ of $\mathrm{SiO}_{2}$, 70-230 mesh; $\mathrm{CH}_{2} \mathrm{Cl}_{2}$ /acetone (30\%)) to get compound 9 (35.3 mg)

Neonanin C (1): colorless oil; $[\alpha]_{\mathrm{D}}^{28}+22(c=0.17, \mathrm{MeOH})$; IR (KBr) $v_{\max }: 3365,2937,1730,1454$ and $1026 \mathrm{~cm}^{-1}$; HR-ESI-MS $\mathrm{m} / z 243.0870[\mathrm{M}-\mathrm{H}]^{+}$(calculated for $\mathrm{C}_{11} \mathrm{H}_{15} \mathrm{O}_{6}$ at 267.0863); ${ }^{1} \mathrm{H}-\mathrm{NMR}$ $\left(500 \mathrm{MHz}\right.$, in $\left.\mathrm{CDCl}_{3}\right)$ and ${ }^{13} \mathrm{C}-\mathrm{NMR}\left(125 \mathrm{MHz}\right.$, in $\left.\mathrm{CDCl}_{3}\right)$ are shown on Table 1.

Neonanin D (2): colorless oil; $[\alpha]_{\mathrm{D}}^{29}+16(c=0.10, \mathrm{MeOH})$; IR $(\mathrm{KBr}) v_{\max }$ : 3387, 2945, 1720, 1274, 1028 and $715 \mathrm{~cm}^{-1} ; \mathrm{UV}(\mathrm{MeOH}) \lambda_{\max }(\log \varepsilon): 228$ (3.9), 273 (3.4) nm; HR-ESI-MS $m / z 359.1457$ [M + Na] ${ }^{+}$ (calculated for $\mathrm{C}_{18} \mathrm{H}_{24} \mathrm{O}_{6} \mathrm{Na}$ at 359.1465); ${ }^{1} \mathrm{H}-\mathrm{NMR}\left(500 \mathrm{MHz}\right.$, in $\left.\mathrm{CDCl}_{3}\right)$ and ${ }^{13} \mathrm{C}-\mathrm{NMR}(125 \mathrm{MHz}$, in $\mathrm{CDCl}_{3}$ ) are shown on Table 1.

Reticunin A (3): colorless oil; $[\alpha]_{\mathrm{D}}^{28}+32(c=0.07, \mathrm{MeOH})$; IR (KBr) $v_{\max }: 3387,2931,1722,1633$, 1446, 1176 and $1006 \mathrm{~cm}^{-1}$; UV (MeOH) $\lambda_{\max }(\log \varepsilon): 236$ (3.6) nm; HR-ESI-MS m/z 453.17553 [M + Na] ${ }^{+}$ (calculated for $\left.\mathrm{C}_{22} \mathrm{H}_{29} \mathrm{O}_{10} 453.17752\right)$; ${ }^{1} \mathrm{H}-\mathrm{NMR}$ (500 MHz, in $\mathrm{CDCl}_{3}$ ) and ${ }^{13} \mathrm{C}-\mathrm{NMR}(125 \mathrm{MHz}$, in $\mathrm{CDCl}_{3}$ ) are shown on Table 2.

Reticunin B (4): colorless oil; M; $[\alpha]_{\mathrm{D}}^{28}+27(c=0.05, \mathrm{MeOH}) ; \mathrm{IR}(\mathrm{KBr}) v_{\max }$ : 3414, 2953, 2918, 2850, 1734, 1462 and $1180 \mathrm{~cm}^{-1}$; HR-ESI-MS $m / z 453.1767[\mathrm{M}-\mathrm{H}]^{+}$(calculated for $\mathrm{C}_{22} \mathrm{H}_{29} \mathrm{O}_{10}$ 453.1755); ${ }^{1} \mathrm{H}-\mathrm{NMR}\left(500 \mathrm{MHz}\right.$, in $\left.\mathrm{CDCl}_{3}\right)$ and ${ }^{13} \mathrm{C}-\mathrm{NMR}\left(125 \mathrm{MHz}\right.$, in $\left.\mathrm{CDCl}_{3}\right)$ are shown on Table 2.

\subsection{Cell Culture}

RAW264.7 the mouse macrophages cell line (Bioresource Collection and Research Center (BCRC) Number: 60001) was obtained from Food Industry Research and Development Institute (Hsinchu, Taiwan). All of the cell lines were cultured in DMEM containing 10\% (v:v) fetal bovine serum (FBS), penicillin and streptomycin $(100 \mathrm{U} / \mathrm{mL}), 4 \mathrm{mM} \mathrm{L}$-glutamine $(100 \mathrm{U} / \mathrm{mL})$. The cells were cultured in a humidified incubator under $5 \% \mathrm{CO}_{2}$ at $37^{\circ} \mathrm{C}$. The RAW264.7 cells $\left(5 \times 10^{5}\right.$ cells per mL) were seeded into plates for $24 \mathrm{~h}$ before treatment.

\subsection{Cell Viability Assay}

The in-vitro cell viability activity of $\mathrm{MeOH}$ extracts, partition fractions and pure compounds were determined by the MTT assay. RAW264.7 cells $\left(5 \times 10^{4} /\right.$ well $)$ were seeded in 96-well plates and incubated for $24 \mathrm{~h}$. The cells were treated with $\mathrm{MeOH}$ extracts and contain partition fractions in various concentrations $(0,62.5,125,250,500$ and $1000 \mu \mathrm{g} / \mathrm{mL})$, compounds and positive control $(0,6.25$, $12.5,25,50$ and $100 \mu \mathrm{g} / \mathrm{mL})$ in the presence or absence of LPS $(100 \mathrm{ng} / \mathrm{mL})$ for $24 \mathrm{~h}$. After $24 \mathrm{~h}$, the medium was replaced with a medium containing $0.5 \mathrm{mg} / \mathrm{mL}$ MTT solution and incubated at $37^{\circ} \mathrm{C}$ for $4 \mathrm{~h}$. After the end of the MTT reaction, we used $0.04 \mathrm{~N} \mathrm{HCl}$ /isopropanol solution to dissolve the formazan crystals. The absorbance was measured at $570 \mathrm{~nm}$ using a microplate reader (Molecular Devices, LLC.). The cell viability was calculated and compared with the control group.

\subsection{NO Assay}

The supernatant collected from cell culture and mixed with an equal volume of Griess reagent ( $1 \%$ sulphanilamide, $0.1 \%$ naphthylethylenediamine dihydrochloride and $5 \%$ phosphoric acid) and the absorbance value was measured at $540 \mathrm{~nm}$ using an ELISA plate reader. 


\subsection{Statistical Analysis}

The $\mathrm{IC}_{50}$ values for $\mathrm{NO}$ production were presented as mean values $\pm \mathrm{SD}$ (standard deviations) of at least three independent experiments. The statistical significance of the differences was evaluated using Student's t-test using IBM SPSS v.20.0 (SPSS Inc., Chicago, IL, USA). The percentage of NO production and cell viability were compared using variance analysis with GraphPad Prism 7.0 (GraphPad Software Inc., San Diego, CA, USA).

\section{Conclusions}

In conclusion, four iridoid derivatives, together with sixteen known compounds were identified in this work. Compounds 7, 10, 12, 14, 15 exhibited inhibitory activities with $\mathrm{IC}_{50}$ values compare to indomethacin (positive control). Syringaresinol (10) displayed the most NO inhibitory ability with $\mathrm{IC}_{50}$ values at $9.18 \pm 1.90 \mu \mathrm{g} / \mathrm{mL}$ which is 5 fold less then indomethacin (positive control) $(46.71 \pm 3.14 \mu \mathrm{g} / \mathrm{mL}$ ) and shows a significant difference. This is the first study that has provided preliminary evidence on the inhibition ability of NO produced by LPS-stimulated RAW 264.7 cells from Neonauclea reticulata (Havil.) Merr. According to our bioassay result and literatures, we propose that the position and numbers of methoxyl group [45] on the benzene ring in the structure of lignan constituents and aromatic compounds with catechol moiety [46] and carboxylic acid side chain [47] were important for this activity. NO is an important mediator in the process of inflammation and anti-inflammatory agents plays a key role in multiple chronic disease treatment; we believe these compounds from N.reticulata could be potential lead compounds in drug discovery. Although we only provide very preliminary result of anti-inflammatory effect, our findings still provide important information for researchers in future work and further study to explore anti-inflammatory mechanism is needed.

Supplementary Materials: The following are available online: 1D- and 2D-NMR, as well as HR-ESI-MS spectra of Compounds 1-4.

Author Contributions: F.-P.C. carried out the experimental work, including chromatographic fractionation and purification of compounds; performed the structure elucidation of the chemicals; analyzed the spectroscopic data; and prepared the manuscript. S.-S.H. and T.-F.K. carried out the experimental work including the bioassay of the extraction and partition. T.-H.L. and C.-I.C. carried out the experimental work including analyzed the spectroscopic data of all know compounds. G.-J.H. and Y.-H.K. participated in the design of this study and organized all the research for it. All authors approved the final version of the manuscript.

Funding: This work was financially supported by Taiwan Ministry of Health and Welfare Clinical Trial Center (MOHW108-TDU-B-212-133004) and "Chinese Medicine Research Center, China Medical University" from The Featured Areas Research Center Program within the framework of the Higher Education Sprout Project by the Ministry of Education (MOE) in Taiwan (CMRC-CHM-4).

Acknowledgments: The statistical analysis in this work performed by Shang-Hua Wu (Department of Pharmacy, Songde Branch, Taipei City Hospital, Taipei 110, Taiwan) are greatly appreciated.

Conflicts of Interest: The authors declare no conflicts of interest.

\section{References}

1. Ordas, J.A.D.; Banag, C.I.; Alejandro, G.J.D. Neonauclea viridiflora (Rubiaceae), a New Species of Naucleeae from Eastern Samar, with Notes on Myrmecophytic Species in the Philippines. Syst. Bot. 2017, 42, 364-370. [CrossRef]

2. Ordas, J.A.D.; Taradji, A.R.J.; Valdez, M.B., Jr.; Banag, C.I.; Alejandro, G.J.D. Neonauclea connicalycina: A new myrmecophytic species of Naucleeae (Rubiaceae) from Cebu, Philippines. Phytotaxa 2016, 273, 127-132. [CrossRef]

3. Yang, T.Y.A. Neonauclea Merr. In Flora of Taiwan, 2nd ed.; The College of Science and Agriculture, National Taiwan University: Taipei, Taiwan, 1998; pp. 304-306.

4. Cheng, H.W.; Wang, K.C.; Liau, S.H.; Sh, N.P. The Structure and Woody Material of the Yami's Planked Boats on Botel Tobago. J. East. Taiwan Stud. 2002, 7, 3-44. 
5. Tosa, H.; Iinuma, M.; Asai, F.; Tanaka, T.; Nozaki, H.; Ikeda, S.; Tsutsui, K.; Tsutsui, K.; Yamada, M.; Fujimori, S. Anthraquinones from Neonauclea calycina and their inhibitory activity against DNA topoisomerase II. Biol. Pharm. Bull. 1998, 21, 641-642. [CrossRef] [PubMed]

6. Atta ur, R.; Vohra, I.I.; Choudhary, M.I.; de Silva, L.B.; Herath, W.H.M.W.; Navaratne, K.M. Neozeylanicine: A Novel Alkaloid from the Timber of Neonauclea zeylanica. Planta Med. 1988, 54, 461-462.

7. Kang, W.Y.; Zhang, B.R.; Hao, X.J. Isolation and Identification of a New Triterpene from Neonauclea sessilifolia. Chem. J. Chin. Univ. 2007, 28, 2096-2098.

8. Itoh, A.; Tanahashi, T.; Nagakura, N.; Nishi, T. Two Triterpenoid Saponins from Neonauclea sessilifolia. Chem. Pharm. Bull. 2003, 51, 1335-1337. [CrossRef]

9. Chang, F.P.; Chao, W.; Wang, S.Y.; Huang, H.C.; Sung, P.J.; Chen, J.J.; Cheng, M.J.; Huang, G.J.; Kuo, Y.H. Three New Iridoid Derivatives Have Been Isolated from the Stems of Neonauclea reticulata (Havil.) Merr. with Cytotoxic Activity on Hepatocellular Carcinoma Cells. Molecules 2018, 23, 2297. [CrossRef]

10. Chiang, H.M.; Chen, H.C.; Chiu, H.H.; Chen, C.W.; Wang, S.M.; Wen, K.C. Neonauclea reticulata (Havil.) Merr Stimulates Skin Regeneration after UVB Exposure via ROS Scavenging and Modulation of the MAPK/MMPs/Collagen Pathway. Evid. Based Complement. Altern. Med. 2013, 2013, 1-9. [CrossRef]

11. Moon, S.M.; Lee, S.A.; Hong, J.H.; Kim, J.S.; Kim, D.K.; Kim, C.S. Oleamide suppresses inflammatory responses in LPS-induced RAW264.7 murine macrophages and alleviates paw edema in a carrageenan-induced inflammatory rat model. Int. Immunopharmacol. 2018, 56, 179-185. [CrossRef]

12. Pan, M.H.; Chiou, Y.S.; Tsai, M.L.; Ho, C.T. Anti-inflammatory activity of traditional Chinese medicinal herbs. J. Tradit. Complement. Med. 2011, 1, 8-24. [CrossRef]

13. Li, P.Y.; Liang, Y.C.; Sheu, M.J.; Huang, S.S.; Chao, C.Y.; Kuo, Y.H.; Huang, G.J. Alpinumisoflavone attenuates lipopolysaccharide-induced acute lung injury by regulating the effects of anti-oxidation and anti-inflammation both in vitro and in vivo. RSC Adv. 2018, 8, 31515-31528. [CrossRef]

14. Liu, Y.; Li, D.; Jiang, Q.; Zhang, Q.; Liu, P.; Wang, L.; Zong, M.; Zhang, Q.; Li, H.; An, Y.; et al. (3R, 7R)-7-Acetoxyl-9-Oxo-de-O-Methyllasiodiplodin, a Secondary Metabolite of Penicillium Sp., Inhibits LPS-Mediated Inflammation in RAW 264.7 Macrophages through Blocking ERK/MAPKs and NF-kappaB Signaling Pathways. Inflammation 2019, 42, 1463-1473. [CrossRef] [PubMed]

15. Michel, S.; Skaltsounis, A.L.; Tillequin, F.; Koch, M.; Assi, L.A. Alcaloïdes des Feuilles de Strychnos dinklagei. J. Nat. Prod. 1985, 48, 86-92. [CrossRef]

16. Huiyan, Z.; Wenmei, Y.; Dechang, C.; Qitai, Z. An iridoid from Siphonostegia chinensis. Phytochemistry 1992, 31, 3268-3269. [CrossRef]

17. Salam, A.; Ray, S.; Zaid, M.A.; Kumar, D.; Khan, T. Total syntheses of several iridolactones and the putative structure of noriridoid scholarein A: An intramolecular Pauson-Khand reaction based one-stop synthetic solution. Org. Biomol. Chem. 2019, 17, 6831-6842. [CrossRef]

18. Borges, C.M.P.; Diakanawma, C.; Mendonça, D.I.M.D.d. Iridoids from Hymenodictyon floribundum. J. Braz. Chem. Soc. 2010, 21, 1121-1125. [CrossRef]

19. Topcu, G.; Che, C.T.; Cordell, G.A.; Ruangrungsi, N. Iridolactones from Alyxia reinwardti. Phytochemistry 1990, 29, 3197-3199. [CrossRef]

20. Xiong, R.; Jiang, J.; Chen, Y. Cytotoxic lignans from Cryptocarya impressinervia. Nat. Prod. Res. 2019, 1-5. [CrossRef]

21. Sribuhom, T.; Sriphana, U.; Thongsri, Y.; Yenjai, C. Chemical constituents from the stems of Alyxia schlechteri. Phytochem. Lett. 2015, 11, 80-84. [CrossRef]

22. Wen, L.; Wei, Q.; Chen, G.; Cai, J.; She, Z. Chemical Constituents From the Mangrove Endophytic Fungus Sporothrix sp. Chem. Nat. Compd. 2013,49,137-140. [CrossRef]

23. Azzizudin; Makhmoor, T.; Choudhary, M.I. Radical scavenging potential of compounds isolated from Vitex agnus-castus. Turk. J. Chem. 2010, 34, 119-126.

24. Al Musayeib, N.; Perveen, S.; Fatima, I.; Nasir, M.; Hussain, A. Antioxidant, Anti-Glycation and Anti-Inflammatory Activities of Phenolic Constituents from Cordia sinensis. Molecules 2011, 16, 10214-10226. [CrossRef] [PubMed]

25. Yannick Stephane, F.F.; Dawe, A.; Angelbert Fusi, A.; Jean Jules, B.K.; Ulrich, K.K.D.; Lateef, M.; Bruno, L.N.; Ali, M.S.; Ngouela, S.A. Crotoliganfuran, a new clerodane-type furano-diterpenoid from Croton oligandrus Pierre ex Hutch. Nat. Prod. Res. 2019, 1-9. [CrossRef] [PubMed] 
26. Jones, L.; Bartholomew, B.; Latif, Z.; Sarker, S.D.; Nash, R.J. Constituents of Cassia laevigata. Fitoterapia 2000, 71, 580-583. [CrossRef]

27. Yang, D.; Xie, H.; Yang, B.; Wei, X. Two tetrahydroisoquinoline alkaloids from the fruit of Averrhoa carambola. Phytochem. Lett. 2014, 7, 217-220. [CrossRef]

28. Tran, T.T.; Kim, M.; Jang, Y.; Lee, H.W.; Nguyen, H.T.; Nguyen, T.N.; Park, H.W.; Dang, Q.L.; Kim, J.C. Characterization and mechanisms of anti-influenza virus metabolites isolated from the Vietnamese medicinal plant Polygonum chinense. BMC Complement. Altern. Med. 2017, 17, 162. [CrossRef]

29. Liu, J.; Li, C.J.; Du, Y.Q.; Li, L.; Sun, H.; Chen, N.H.; Zhang, D.M. Bioactive Compounds from the Stems of Clausena lansium. Molecules 2017, 22, 2226. [CrossRef]

30. Ji, L.L.; Wang, X.; Li, J.J.; Zhong, X.J.; Zhang, B.; Juan, J.; Shang, X.Y. New Iridoid Derivatives from the Fruits of Cornus officinalis and Their Neuroprotective Activities. Molecules 2019, 24, 625. [CrossRef]

31. Horn, M.M.; Drewes, S.E.; Brown, N.J.; Munro, O.Q.; Meyer, J.J.M.; Mathekga, A.D.M. Transformation of naturally-occurring 1,9-trans-9,5-cis sweroside to all trans sweroside during acetylation of sweroside aglycone. Phytochemistry 2001, 57, 51-56. [CrossRef]

32. Hart, N.K.; Johns, S.R.; Lamberton, J.A. Alkaloids of Jasminum species (family Oleaceae). II. Isolation of a new monoterpenoid alkaloid and other constituents. Aust. J. Chem. 1969, 22, 1283-1290. [CrossRef]

33. Vane, J.R.; Botting, R.M. Mechanism of Action of Nonsteroidal Anti-inflammatory Drugs. Am. J. Med. 1998, 104, 2S-8S. [CrossRef]

34. Borthakur, A.; Bhattacharyya, S.; Dudeja, P.K.; Tobacman, J.K. Carrageenan induces interleukin-8 production through distinct Bcl10 pathway in normal human colonic epithelial cells. Am. J. Physiol. Gastrointest. Liver Physiol. 2007, 292, G829-G838. [CrossRef] [PubMed]

35. Min, S.W.; Ryu, S.N.; Kim, D.H. Anti-inflammatory effects of black rice, cyanidin-3-O- $\beta$-d-glycoside, and its metabolites, cyanidin and protocatechuic acid. Int. Immunopharmacol. 2010, 10, 959-966. [CrossRef] [PubMed]

36. Cario, E.; Rosenberg, I.M.; Brandwein, S.L.; Beck, P.L.; Reinecker, H.C.; Podolsky, D.K. Lipopolysaccharide Activates Distinct Signaling Pathways in Intestinal Epithelial Cell Lines Expressing Toll-Like Receptors. J. Immunol. 2000, 164, 966-972. [CrossRef] [PubMed]

37. Hussain, T.; Tan, B.; Yin, Y.; Blachier, F.; Tossou, M.C.B.; Rahu, N. Oxidative Stress and Inflammation: What Polyphenols Can Do for Us? Oxidative Med. Cell. Longev. 2016, 2016, 9. [CrossRef] [PubMed]

38. Bajpai, V.K.; Alam, M.B.; Quan, K.T.; Ju, M.K.; Majumder, R.; Shukla, S.; Huh, Y.S.; Na, M.; Lee, S.H.; Han, Y.K. Attenuation of inflammatory responses by (+)-syringaresinol via MAP-Kinase-mediated suppression of NF-kB signaling in vitro and in vivo. Sci. Rep. 2018, 8, 9216. [CrossRef]

39. Chin, Y.W.; Chai, H.B.; Keller, W.J.; Kinghorn, A.D. Lignans and Other Constituents of the Fruits of Euterpe oleracea (Açai) with Antioxidant and Cytoprotective Activities. J. Agric. Food Chem. 2008, 56, 7759-7764. [CrossRef]

40. Bufalo, M.; Ferreira, I.; Costa, G.; Francisco, V.; Liberal, J.; Cruz, M.; Lopes, M.; Batista, M.; Sforcin, J. Propolis and its constituent caffeic acid suppress LPS-stimulated pro-inflammatory response by blocking NF- $\mathrm{KB}$ and MAPK activation in macrophages. J. Ethnopharmacol. 2013, 149, 84-92. [CrossRef]

41. Quispe, Y.N.G.; Hwang, S.H.; Wang, Z.; Zuo, G.; Lim, S.S. Screening In Vitro Targets Related to Diabetes in Herbal Extracts from Peru: Identification of Active Compounds in Hypericum laricifolium Juss. by Offline High-Performance Liquid Chromatography. Int. J. Mol. Sci. 2017, 18, 2512. [CrossRef]

42. Huang, S.W.; Qiao, J.W.; Sun, X.; Gao, P.Y.; Li, L.Z.; Liu, Q.B.; Sun, B.; Wu, D.L.; Song, S.J. Secoiridoids and lignans from the leaves of Diospyros kaki Thunb. with antioxidant and neuroprotective activities. J. Funct. Foods 2016, 24, 183-195. [CrossRef]

43. Lee, J.W.; Lee, J.H.; Lee, C.; Jin, Q.; Lee, D.; Kim, Y.; Hong, J.T.; Lee, M.K.; Hwang, B.Y. Inhibitory constituents of Sophora tonkinensis on nitric oxide production in RAW 264.7 macrophages. Bioorg. Med. Chem. Lett. 2015, 25, 960-962. [CrossRef] [PubMed]

44. Dai, J.Q.; Liu, Z.L.; Yang, L. Non-glycosidic iridoids from Cymbaria mongolica. Phytochemistry 2002, 59, 537-542. [CrossRef]

45. Yang, H.; Du, Z.; Wang, W.; Song, M.; Sanidad, K.; Sukamtoh, E.; Zheng, J.; Tian, L.; Xiao, H.; Liu, Z.; et al. Structure-Activity Relationship of Curcumin: Role of the Methoxy Group in Anti-inflammatory and Anticolitis Effects of Curcumin. J. Agric. Food Chem. 2017, 65, 4509-4515. [CrossRef] [PubMed] 
46. Zheng, L.T.; Ryu, G.M.; Kwon, B.M.; Lee, W.H.; Suk, K. Anti-inflammatory effects of catechols in lipopolysaccharide-stimulated microglia cells: Inhibition of microglial neurotoxicity. Eur. J. Pharmacol. 2008, 588, 106-113. [CrossRef] [PubMed]

47. Murakami, Y.; Kawata, A.; Suzuki, S.; Fujisawa, S. Cytotoxicity and Pro-/Anti-inflammatory Properties of Cinnamates, Acrylates and Methacrylates Against RAW264.7 Cells. In Vivo 2018, 32, 1309-1322. [CrossRef] [PubMed]

Sample Availability: Samples of the compounds 1-20 are available from the authors.

(C) 2019 by the authors. Licensee MDPI, Basel, Switzerland. This article is an open access article distributed under the terms and conditions of the Creative Commons Attribution (CC BY) license (http://creativecommons.org/licenses/by/4.0/). 